\title{
ACNE VULGARIS: PSYCHOSOCIAL IMPACT IN ADOLESCENTS
}

\author{
Jahagirdar Rohan https://orcid.org/0000-0001-8287-9562 \\ Zydus Medical College and Hospital, Dahod, Gujarat, India \\ rohanjahagirdar@outlook.com
}

Relevance. Acne vulgaris is chronic inflammatory disorder which is known to have major psychological impact on adolescents which results in residual scarring and pigmentation. Acne is devastating disease and have significant negative psychosocial impact as their faces being checked by others leading social anxiety.

Objective: this study was conducted with objectives to study psychosocial impact due to acne vulgaris.

Materials and methods. This study includes 200 patients of 15 years and above of acne vulgaris patients. Global Acne Grading System was used to grade severity of acne and dermatology life quality index (DLQI) was used to measure psychosocial quality of life. Data collected was entered into MS excel sheet and statistical analysis was done by SPSS software.

Results. Majority of patients (58\%) were localised mostly on face and with grade - II. $39.5 \%$ were mildly affected $47 \%$ were moderately affected with quality of life in the study.

Conclusions. Significant impact of acne vulgaris was noted on emotional, social, study was noted in adolescent population.

Keywords: acne, adolescence, psychosocial anxiety, quality of life.

Relevance. Acne vulgaris is a common skin disease which affects majority of adolescents with prevalence reaching up to $80 \%$ of adolescence [1]. Humans as a power of expressing bodily emotions like worry (picking), anxiety (pruritis and sweating), fear and anger (urticaria), guilt and shame (blushing), hostility, masochism and eroticism (dermatitis factitia) [2]. Acne may lead to psychological problems, which may negatively affect on dermatological as well as psycho-sociological aspect of quality of life, thus can affect psychological and social functioning. Psychological issues includes dissatisfaction with appearance, embarrassment, self-consciousness, lack of self-confidence, and social dysfunction such as reduced/avoidance of social interactions with friends of same and opposite gender, reduced employment opportunities have been documented [3].

However, there are many studies that discuss the psychological problems and psychiatric symptoms that results in acne, psychosocial anxiety and related factors have not been studied up to date. Keeping the background into consideration, importance of body image in young adolescence and cosmetic problems that acne may result, it is clear that the level of psychosocial anxiety should be assessed in acne patients.

Recent years in Indian society, good appearance and ideal perfect skin has attracted a special importance.

Objective: by taking the lacuna of Indian studies, present study was undertaken to assess impact of acne vulgaris on psychosocial anxiety in adolescents.

\section{MATERIALS AND METHODS}

The study was conducted on 200 acne vulgaris patients in department of psychiatry, Vikhe patil Medical College. Ahmednagar. Ethical approval was taken prior to start the study. Informed consent was taken from all participants included in study.
Inclusion criteria. Patients with definitive diagnosis of acne vulgaris of age 15 years and above were included in study.

Exclusion criteria. Patients with known history of pre-existing psychiatric disorder, concurrent physical illness which can affect mental state, with any other co-morbid medical and dermatological disorder were excluded from study.

After ruling out acne vulgaris and graded acne severity using Global Acne Grading Scale (GAGS) [4] into six grades, patients with definitive diagnosis of acne vulgaris were referred for assessment of psychosocial life by Dermatology life quality index scores DLQ1 [5] questionnaire which includes ten questions having four points $(0,1,2$, and 3$)$. All questions were available in English/ Hindi bilingual language which is validated by two members.

After following exclusion criteria of co-morbid medical and dermatological and pre-existing psychiatric disease 200 consecutive patients with definitive diagnosis of acne vulgaris, were asked to subjectively rate their acne severity on Global Acne Grading Scale (GAGS). Psychosocial assessment was done by using Dermatology life quality index scores (DLQI) questionnaire with sum of all answers (range is from 0 to 30). Interpretation of DLQI score was done as follows: Score (0-1) no effect on patient's life, (2-5) small effect (6-10) moderate effect, (11-20) very large effect, and score (21-30) extremely large effect on patient's life. Acne related clinical variables (site of lesions, clinical and subjective severity) were noted on structured proforma.

Statistical analysis. Data thus obtained were entered in Microsoft office excels 2013 and analysed by using IBM SPSS software version 24. Following test of significance $(\mathrm{P}<0.05)$ were used: $\mathrm{Chi}-$ Square test and Post-hoc test. 


\section{RESULTS AND DISCUSSION}

A total of 200 patients with acne in age range 15-30 years participated in the study. Females was predominated with $61 \%, 52.5 \%$ were in the age group 15-20 years. Majority people were in less than one year duration. Face acne single site involvement was $48.5 \%$, multiple site was seen in face and chest (18\%) as well face and back (15\%). Grade II was highest among, following grade III, Grade I and Grade IV. All these values was presented in table 1.

Table 3 shows the comparison of significance between Global Acne Grading Scale (GAGS) and Dermatology Life quality Index Scores (DLQI). Statistically significant correlation $(\mathrm{P}<0.05)$ was seen between all the parameters except treatment taking time $(\mathrm{P}>0.05)$

This was a cross sectional study in which 200 patients of acne vulgaris between age group 15-30 years were assessed for psychosocial anxiety. When the satisfaction of good looking in Indian society is gaining importance now a days our study showed negative influence of acne vulgaris on psychosocial behaviour. Skin disorders are associated with various factors like age, gender, nutritional status and stress $[6,7,8]$. Similar to our findings, a study done by Neirita et al, reported that acne vulgaris affects the emotional status, interpersonal, personal and social activities [9].

Our study could support to many researches addressing the connection between acne and psychosocial problems. High level of social anxiety and consciousness in acne patients is at peak in teenagers which can affect the learning and social interaction. Therefore acne teenage patients may lack the self-confidence to go out
Table 1

\section{Characteristics of participants}

\begin{tabular}{|c|c|c|}
\hline Parameter & Parameter characteristic & $\mathbf{n}$ \\
\hline \multirow{2}{*}{ Gender } & Male & 78 \\
\hline & Female & 122 \\
\hline \multirow{3}{*}{ Age (years) } & $15-20$ & 105 \\
\hline & $21-25$ & 70 \\
\hline & $26-30$ & 25 \\
\hline \multirow{4}{*}{$\begin{array}{l}\text { Duration of acne } \\
\quad \text { (years) }\end{array}$} & $<1$ & 80 \\
\hline & $1-2$ & 58 \\
\hline & $2-3$ & 39 \\
\hline & $3-4$ & 23 \\
\hline \multirow{7}{*}{ Site } & Face & 97 \\
\hline & Chest & 02 \\
\hline & Back & 12 \\
\hline & Face and chest & 36 \\
\hline & Face and back & 30 \\
\hline & Chest and back & 05 \\
\hline & Face, chest and back & 18 \\
\hline \multirow{4}{*}{ Grade } & I & 25 \\
\hline & II & 116 \\
\hline & III & 35 \\
\hline & IV & 24 \\
\hline
\end{tabular}

with friends into community and develop relationships. Importantly there is negative appraisal, feeling of shame and social uneasiness that they would be judged as unattractive by opposite person of same and opposite

Table 2

Dermatology life quality index scores of all subjects

\begin{tabular}{|c|c|c|c|c|c|}
\hline $\begin{array}{c}\text { Total number } \\
\text { of subject's, } \boldsymbol{n} \text { (\%) }\end{array}$ & $\begin{array}{c}\text { No effect } \\
(\text { score 0-1), } \boldsymbol{n}(\%)\end{array}$ & $\begin{array}{c}\text { Mild effect } \\
(\text { score 2-5), } \boldsymbol{n}(\%)\end{array}$ & $\begin{array}{c}\text { Moderate effect } \\
(\text { score 6-10), } \boldsymbol{n}(\%)\end{array}$ & $\begin{array}{c}\text { Very large effect } \\
\text { (score 11-20), } \boldsymbol{n}(\%)\end{array}$ & $\begin{array}{c}\text { Extreme large effect } \\
\text { (score 21-30), } \boldsymbol{n}(\%)\end{array}$ \\
\hline $200(100)$ & $2(1)$ & $79(39.5)$ & $94(47)$ & $25(12.5)$ & $0(0)$ \\
\hline
\end{tabular}

Table 3

Significance of correlation (P) between Global Acne Grading Scale (GAGS) and Dermatology Life quality Index Scores (DLQI)

\begin{tabular}{|c|c|c|}
\hline Demographic characters & Site of lesions & Grade of acne \\
\hline 1: Physical symptoms & 0.004 & 0.005 \\
\hline Q2: Embarrassment/self-consciousness & 0.003 & 0.001 \\
\hline Q3: Effect on daily activities & 0.040 & 0.010 \\
\hline Q4: Choice of clothes and site of acne & 0.044 & 0.040 \\
\hline Q5: Effect on social activities & 0.005 & 0.010 \\
\hline Q6: Sports & 0.705 & 0.500 \\
\hline Q7: Effect on work/study & 0.004 & 0.011 \\
\hline Q8: Problems with partner/friends & 0.001 & 0.005 \\
\hline Q9: Sexual difficulties showed & 0.001 & 0.002 \\
\hline Q10: Treatment takingup time/making skin messy & 0.265 & 0.501 \\
\hline
\end{tabular}

Note: $P<0.05$ - significant; ${ }^{*} P>0.05-$ not significant 
gender can lead to social anxiety and avoiding to mingle resulting extreme cases social phobia may be developed in acne patients. Ritvo $\mathrm{E}$ et al, in a survey, by interviewing teenagers founded that most of the teen respondents who had ever had acne; would stay off facebook for a year $(59 \%)$ or not go on a date for a year $(30 \%)$ [8]. When acne locates on the face primarily, it has a greater effect on psychological functioning of individuals. When it is on the back or the chest, it can be covered with clothing, it causes less distress. Korczak et al, found that frequent recurrence of acne on face can result in disappointment of sufferer especially therefore can experience anxiety [10]. We found statistically significant difference between site of lesion and social anxiety.

In our study majority of patients who had acne lesions on face experience more stress which is in relation with the study conducted by Gupta et al, with mild-moderate acne severity experience stress and had social anxiety; and concluded that for acne to lead to psychological problems it need not be severe [11].

There is again a difficulty for female gender with acne, as they are beauty conscious but they can manage them by covering with makeup which will be decreasing embarrassment and self-consciousness [12]. Difficulties in sports, work and studies were also negatively impact in acne patients due to stress which is supported by study conducted by Walker et al [13].

Daily activities including family parties and social gatherings even choice of clothes will become a hectic for acne patients because of dark spots on body which can be body shaming and uncomfortable behaviour [13, 14].

\section{CONCLUSION}

In the present study out of 200 acne patients of acne vulgaris patients most of them had social anxiety, localised on face are in majority. We conclude acne vulgaris is an illness with the potential to cause important psychosocial and psychiatric complications and affect quality of life including employment opportunities.

Implications. There is a need for integration of psychological and psychiatric intervention in the management of acne vulgaris, for improvement in the quality of life in acne vulgaris patients.

Limitations. Absence of control group is the limitation.

\section{Acknowledgements: nil \\ Conflict of interest: nil \\ Financial Disclosure: nil}

\section{REFERENCES}

1. Rzany B, Kahl C. Epidemiology of acne vulgaris. J Dtsch Dermatol Ges. 2006;4:8-9. DOI: 10.1111/j.1610-0387.2005.05876.x

View at:

Publisher Site: https://onlinelibrary.wiley.com/ doi/10.1111/j.1610-0387.2005.05876.x

PubMed: https://pubmed.ncbi.nlm.nih.gov/16503926/

2. Koblenzer CS. Psychosomatic concepts in dermatology. Arch Dermatol. 1983; 119(6): 501-12.

View at:

PubMed: https://pubmed.ncbi.nlm.nih.gov/6859891/

3. Magin P, Adams J, Heading G, Pond D, Smith W. Psychological sequelae of acne vulgaris: Results of a qualitative study. Can Fam Physician. 2006;52(8):978-9.

View at:

PubMed: https://pubmed.ncbi.nlm.nih. gov/17273501/

PubMed Central: https://www.ncbi.nlm.nih.gov/pmc/ articles/PMC1781509/

4. Doshi A, Zaheer A, Stiller MJ. A comparison of current acne grading systems and proposal of a novel system. International Journal of Dermatology. 1997;36(6):416-8. DOI: 10.1046/j.1365-4362.1997.00099.x.

View at:

Publisher Site: https://onlinelibrary.wiley.com/doi/ abs/10.1046/j.1365-4362.1997.00099.x

PubMed: https://pubmed.ncbi.nlm.nih.gov/9248884/

5. Basra MK, Fenech R, Gatt RM, Salek MS, Finlay AY. The Dermatology Life Quality Index 1994-2007: a comprehensive review of validation data and clinical results. Br J Dermatol. 2008; 159(5):997-1035. DOI: 10.1111/j.1365-2133.2008.08832.x.

View at:

Publisher Site: https://onlinelibrary.wiley.com/ doi/10.1111/j.1365-2133.2008.08832.x

PubMed: https://pubmed.ncbi.nlm.nih.gov/18795920/

6. Katzman M, Logan AC. Acne vulgaris: nutritional factors may be influencing psychological sequelae. Medical hypotheses. 2007; 69(5):1080-84. DOI: 10.1016/j. mehy.2007.02.037

View at: Publisher Site: https://www.sciencedirect.com/science/article/abs/pii/ S0306987707002009?via\%3Dihub

PubMed: https://pubmed.ncbi.nlm.nih.gov/17448607/

7. Yarpuz AY, Saadet ED, Sanli HE, Ozguven DH. [Social anxiety level in acne vulgaris patients and its relationship to clinical variables]. Turk Psikiyatri Dergisi. 2008; 19(1): 29-37. [Article in Turkish]

View at:

PubMed: https://pubmed.ncbi.nlm.nih.gov/18330741/

8. Ritvo E, Rosso JQD, Stillman MA, Riche CL. Psychsocial judgements and perceptions of adolescents with acne vulgaris: A blinded, controlled comparision of adult and peer evaluations. Bio Psycho Soc Med. 2011; 5(1):11. DOI: 10.1186/1751-0759-5-11.

View at:

Publisher Site: https://bpsmedicine.biomedcentral.com/ articles/10.1186/1751-0759-5-11

PubMed: https://pubmed.ncbi.nlm.nih.gov/21838915/ PubMed Central: https:/www.ncbi.nlm.nih.gov/pmc/ articles/PMC3171294/

9. Hazairika N, Archana M. The Psychosocial Impact 
of Acne Vulgaris. Indian J Dermatol. 2016 Sep-Oct; 61(5): 515-20. DOI: 10.4103/0019-5154.190102

View at:

Publisher Site: https://www.e-ijd.org/article.as$\mathrm{p} ?$ issn $=0019-5154$; year $=2016$; volume $=61$; is sue $=5 ;$ spage $=515 ;$ epage $=520 ;$ aulast $=$ Hazarika

PubMed: https://pubmed.ncbi.nlm.nih.gov/27688440/ PubMed Central: https:/www.ncbi.nlm.nih.gov/pmc/ articles/PMC5029236/

10. Korczak D. [The psychological status of acne patients. Personality structure and physician-patient relations]. Fortschr Med. 1989; 107(14):309-13. [Article in German]

View at:

PubMed: https://pubmed.ncbi.nlm.nih.gov/2526784/

11. Gupta MA, Gupta AK, Schork NJ, Ellis CN, Voorhees JJ. Psychiatric aspects of the treatment of mild to moderate facial acne. Int J Dermatol. 1990; 29(10): 719-21.

View at:

Publisher Site: https://onlinelibrary.wiley.com/ doi/10.1111/j.1365-4362.1990.tb03777.x

PubMed: https://pubmed.ncbi.nlm.nih.gov/2148562/

12. Magin P, Adams J, Heading G, Pond D, Smith W. Psychological sequelae of acne vulgaris: Results of a qualitative study. Can Fam Physician. 2006;52(8):978-9.
View at:

PubMed: https://pubmed.ncbi.nlm.nih.gov/17273501/ PubMed Central: https:/www.ncbi.nlm.nih.gov/pmc/ articles/PMC1781509/

13. Walker N, Lewis-Jones MS. Quality of life and acne in Scottish adolescent schoolchildren: Use of the Children's Dermatology Life Quality Index (CDLQI) and the Cardiff Acne Disability Index (CADI). J Eur Acad Dermatol Venereol. 2006;20(1):45-50. DOI: 10.1111/j.1468-3083.2005.01344.x.

View at:

Publisher Site: https://onlinelibrary.wiley.com/ doi/10.1111/j.1468-3083.2005.01344.x

PubMed: https://pubmed.ncbi.nlm.nih.gov/16405607/

14. Kellet SC, Gawkroger DJ. The psychological and emotional impact of acne and the effect of treatment with isotretinoin. Brit J Dermatol. 1999; 140(2): 272-82. DOI: 10.1046/j.1365-2133.1999.02662.x.

View at:

Publisher Site: https://onlinelibrary.wiley.com/doi/ abs/10.1046/j.1365-2133.1999.02662.x

PubMed: https://pubmed.ncbi.nlm.nih.gov/10233222/

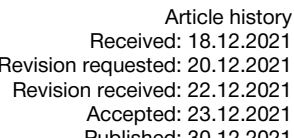
Published: 30.12 .2021

\title{
ВУГРОВА ХВОРОБА: ПСИХОСОЦІАЛЬНИЙ ВПЛИВ НА ПІДЛІТКІВ
}

\author{
Джахагірдар Рохан \\ Медичний коледж та клініка Зідуса, Даход, штат Гуджарат, Індія \\ rohanjahagirdar@outlook.com
}

\begin{abstract}
Актуальність. Акне вульгаріс (вульгарні вугри) - це хронічне захворювання, яке, як відомо, призводить до серйозного психологічного впливу на підлітків і призводить до залишкових рубців та пігментації. Вульгарні вугри - деструктивне захворювання, так як має значний негативний психологічний вплив, оскільки обличчя хворих оцінюється іншими людьми, це тягне за собою розвиток соціальної тривоги.

Мета: дослідити психосоціальний вплив вульгарних вугрів на підлітків.

Матеріали та методи. До цього дослідження було включено 200 пацієнтів з акне у віці 15 років і більше. Глобальна система оцінки акне використовувалася для оцінки ступеня тяжкості акне, а дерматологічний індекс якості життя (ДІЯЖ) використовувався для вимірювання психосоціальної якості життя. Зібрані дані вводилися до таблиці MS Excel, а статистичний аналіз проводився за допомогою програмного забезпечення SPSS.

Результати. У більшості пацієнтів (58\%) акне локалізувалося переважно на обличчі та з ІІ ступенем ураження. У $39,5 \%$ пацієнтів угрі мали легкий вплив на якість життя, у 47\% - помірний вплив.

Висновки. Відзначено достовірний вплив вульгарних вугрів на емоційний та соціальний стан досліджуваних підлітків.

Ключові слова: вугри, підлітковий вік, психосоціальна тривожність, якість життя.
\end{abstract}

\section{УГРЕВАЯ БОЛЕЗНЬ: ПСИХОСОЦИАЛЬНОЕ ВЛИЯНИЕ НА ПОДРОСТКОВ}

\author{
Джсахагирдар Рохан \\ Медииинский колледж и клиника Зидуса, Даход, штат Гуджсарат, Индия \\ rohanjahagirdar@outlook.com
}

\footnotetext{
Актуальность. Акне вульгарис (вульгарные угри) - это хроническое заболевание, которое, как известно, оказывает серьезное психологическое воздействие на подростков и приводит к остаточным рубцам и пигментации. Вульгарные угри - деструк-
} 
тивное заболевание, так как оказывает значительное негативное психологическое воздействие, поскольку лица больных оцениваются другими людьми, это влечет за собой развитие социальной тревоги.

Цель: изучить психосоциальное влияния вульгарных угрей на подростков.

Методы. В это исследование были включены 200 пациентов с акне в возрасте 15 лет и старше. Глобальная система оценки акне использовалась для оценки степени тяжести акне, а дерматологический индекс качества жизни (ДИКЖ) использовался для измерения психосоциального качества жизни. Собранные данные вводились в таблицу MS Excel, а статистический анализ проводился с помощью программного обеспечения SPSS.

Результаты. У большинства пациентов (58\%) акне локализовалось преимущественно на лице и со II степенью поражения. У $39,5 \%$ угри имели легкое влияние на качество жизни, у 47\% - умеренное влияние.

Выводы. Отмечено достоверное влияние акне вульгарис (вульгарных угрей) на эмоциональное и социальное состояние среди исследованных пациентов подросткового возраста.

Ключевые слова: угри, подростковый возраст, психосоциальная тревожность, качество жизни. 